\title{
Immunopharmacological activity of calcitriol pre-treated RAW264.7 cell line stimulated by phorbol 12-myristate13-acetate (PMA) and Formyl-methionyl-leucyl-phenylalanine (FMLP) agonist
}

\author{
Samson Ayodeji Olofinsae ${ }^{1}$, Bartholomew Okechukwu Ibeh ${ }^{2, *}$, Habu Josiah Bitrus ${ }^{3}$, \\ Jatinder Ahluwalia ${ }^{1}$ \\ ${ }^{1}$ School of Health, Sport and Bioscience, University of East London, United Kingdom \\ ${ }^{2}$ Departments of Medical Biotechnology, National Biotechnology Development Agency, Abuja, Nigeria \\ ${ }^{3}$ Bioresources Development Center, Odi, National Biotechnology Development Agency, Nigeria
}

Email address:

barthokeyibeh@yahoo.com (B. O. Ibeh)

\section{To cite this article:}

Samson Ayodeji Olofinsae, Bartholomew Okechukwu Ibeh, Jatinder Ahluwalia. Immunopharmacological Activity of Calcitriol Pre-Treated RAW264.7 Cell Line Stimulated by Phorbol 12-Myristate13-Acetate (PMA) and Formyl-Methionyl-Leucyl-Phenylalanine (FMLP) Agonist. American Journal of Bioscience and Bioengineering. Vol. 2, No. 4, 2014, pp. 55-59. doi: 10.11648/j.bio.20140204.11

\begin{abstract}
The study investigates the effect of calcitriol treatment on oxygen consumption rate as generated by agonist stimulation of RAW 264.7 cell lines and its usefulness in eliciting reduced oxygen consumption in high respiratory burst-dependent disease state. Phorbol 12-myristate 13-acetate (PMA) and Formyl-methionyl-leucyl-phenylalanine (FMLP) were used to artificially stimulate oxygen consumption in cultured pro-monocytic RAW264.7 cell line. Samples of the cultured cells were previously prepared with calcitriol $\left(1,25\right.$ - Dihydroxyvitamin $\mathrm{D}_{3}$ ) followed by a 72 -hour incubation period. The percentage oxygen consumption was measured using the Clark oxygen electrode. There was a significant increase in oxygen consumption in FMLP treated cells $(\mathrm{P}<0.05)$ when compared with the PMA and the control groups. The PMA calcitriol-treated cells showed $24 \%$ oxygen consumption rate more than the control while FMLP treated cells was $57 \%$ higher. The result demonstrated that calcitriol, a known stimulant used to prep most cells for agonists stimulation of oxygen consumption may serve as a physiological moderator of oxygen consumption in immune cells when co-administered with agonist (PMA and/or FMLP). This may result to increased pathogen attack in a diseased state.
\end{abstract}

Keywords: Respiratory Burst, Immunity, Oxidation, NADPH Oxidase, Promonocytes, RAW264.7, Calcitriol

\section{Introduction}

Respiratory burst is the rapid release of reactive oxygen species usually from immune cells such as neutrophils and monocytes when they are stimulated by microorganism or pathogens. Respiratory burst plays an important role in the human immune system [1]. It is a crucial reaction that occurs in phagocytes to degrade internalized particles and bacteria [2].

RAW264.7 cell lines are macrophage-like cells derived from $\mathrm{Balb} / \mathrm{c}$ mice. They maintain many of the properties of macrophages including nitric oxide production, phagocytosis, extreme sensitivity to TLR agonists and motility [3]. These cells are the most commonly used mouse macrophage cell line in medical research especially in severe respiratory diseases [4]-[5].
RAW264.7 has a unique efficiency for propagation and DNA transfection, sensitivity to RNA interference [6] and possession of receptors for many relevant ligands. The choice of this cell line was preferred in the study because of its reliability as an appropriate in vitro model for monitoring cell regulation and studying cytokine oxidative burst [7]-[8]. Certain conditions that stimulate differentiation probably may increase the contribution of immune cells to host defense mechanism in diseased or perturbed state. It is generally known that in the human immune response system, neutrophils are the first host cell to arrive at sites of pathogen invasion with an intrinsic capacity to kill invading organism. Immune cells normally release various toxic agents targeted at microbial destruction, this system may rely on potent reactive products of oxygen metabolism that are generated as a result of the respiratory burst. 
The agonists Phorbol 12-myristate 13-acetate (PMA) and Formyl-methionyl-leucyl-phenylalanine (FMLP) stimulate respiratory burst in neutrophils by modifying the function of NADPH-dependent oxidase [9]. Numerous studies have explained the mechanism by which macrophages generate oxidative burst when in contact with or infected by a pathogen [10], [11]. The present study used PMA and FMLP to trigger respiratory burst in RAW264.7 cell line and monitor the effect of calcitriol on the rate of oxygen consumption. This investigation therefore targets the immuno-stimulatory effects of calcitriol on monocytic cell lines measured in terms of their intracellular oxygen consumption.

Obviously, in the human immune response system, neutrophils are the first host cell to arrive at sites of pathogen invasion with an intrinsic capacity to kill a variety of invading organisms. Immune cells regularly release various toxic chemicals targeted at microbial destruction [12, 13]. This process may rely on potent reactive products of oxygen metabolism that are generated as a result of the respiratory burst. Neutrophils and monocytes usually utilize myeloperoxidase [14] to further combine $\mathrm{H}_{2} \mathrm{O}_{2}$ with $\mathrm{Cl}^{-}$to produce hypochlorite that plays part in bacteria destruction. The incidence of respiratory burst features a dramatic increase in oxidative metabolism with direct conversion of molecular oxygen to its univalent reduction product, the superoxide anion $\left(\mathrm{O}^{-.2}\right)$. Subsequent reactions possibly lead to the formation of other toxic species, including hydrogen peroxide $\left(\mathrm{H}_{2} \mathrm{O}_{2}\right)$, hypochlorous acid $(\mathrm{HOCl})$, hydroxyl radical $\left(\mathrm{OH}^{\cdot}\right)$ and singlet oxygen $\left({ }^{1} \mathrm{O}_{2}\right)$ [15,16]. Primary reactive oxygen species (ROS) of immune system origin are produced when molecular oxygen instead of the specific substrate is reduced by acquisition of an electron [17]. Several enzymes that catalyze the transfer of electrons from the reductant (electron donor) to the oxidant (electron acceptor)) have been shown to be a potential source of superoxide in human cell especially the NADPH oxidase $[18,19]$.

The investigation reported here were framed on the hypothesis that calcitriol treatment of promonocytes stimulated with Phorbol 12-myristate 13-acetate (PMA) and Formyl-methionyl-leucyl-phenylalanine (FMLP) would elicit increased reduced oxygen consumption which might be useful in high respiratory burst-dependent disease states.

\section{Materials and Methods}

\subsection{Reagents}

Tissue culture supplies and chemicals were purchased from Sigma-Aldrich specifically Trypan blue, Amphotericin B, Penicillin and Cacitriol (1, 25- Dihydroxyvitamin $\mathrm{D}_{3)}$, PMA (phorbol-12-myristate-13-acetate) and FMLP (formyl-methionyl-leucyl-phenylalanine). RAW264.7 pro-monocytic cell was obtained from European Collection of Cell Culture (ECACC), Salisbury SP4 0JG, UK. All other chemicals used were of analytical grade.

\subsection{Experimental Design, Cell Culture and Cell Stimulation}

RAW264.7 cells were treated with calcitriol and stimulated by either FMLP or PMA agonists. The control received no treatment. The promonocytic non-differentiated RAW264.7 cell lines were cultured using cell culture flasks in DMEM/F12 medium supplemented with $100 \mu \mathrm{M}$ calcitriol. About $20 \mu 1$ of calcitriol was transferred into the RAW264.7 cell suspension, this was incubated for 72 hours. The cells were maintained at $1-10 \times 10^{5}$ cells/ml in DMEM/F12 medium supplemented with RPMI 1640 medium containing $10 \%$ fetal bovine serum (FBS) and $2 \mathrm{mM}$ glutamine. Medium was provided separately with $100 \mathrm{Unit} / \mathrm{ml}$ penicillin and 100 Unit/ml amphotericin B as antibacterial and antifungal agents respectively. The cells were subcultured at $2 \times 10^{5}$ cells $/ \mathrm{ml}$ every 3-4 days; $3 \times 10^{6}$ cells were washed with RPMI and stimulated by culture in either $1 \mu 1$ of $10 \mu \mathrm{M}$ FMLP or $1 \mu \mathrm{l}$ of $1 \mu \mathrm{M}$ phorbol 12-myristate 13 -acetate (PMA) in $3 \mathrm{ml}$ of RPMI with FBS in polypropylene culture tubes for $72 \mathrm{~h}$.

Unstimulated cells were prepared by washing in RPMI and incubating in culture flasks at $3 \times 10^{6}$ cell $/ \mathrm{ml}$ for 24 hours. All experiments were done in triplicates and the controls remain untreated.

\subsection{Estimation of Cell Proliferation and Cell Density}

To estimate cell proliferation, the calcitriol treated RAW264.7 cell suspension and the respective controls were counted in each case after $72 \mathrm{~h}$ of incubation. Cell density was estimated in cells/ml and cells viability checked with trypan blue.

\subsection{Measurement of Respiratory Burst Activity in RAW264.7 Cell Lines}

Measurement of respiratory burst/ $\mathrm{O}_{2}$ consumption was done using a Clark electrode attached to an oxygen-monitoring system (YSI Inc., Yellow Springs) with a chart recorder. The Clark electrode has a comparable sensitivity with MitoXpress fluorescent assay. It offers the unique opportunity to add external compounds during experiments, shows great sensitivity in studying enzymes and chemical reactions that consume oxygen when compared with electron paramagnetic resonance (EPR) oximetry and fluorescent assay [20]. The electrodes: a platinum cathode and silver anode was equilibrated at $37^{\circ} \mathrm{C}$ in a stirred, sealed chamber with a capacity of $350 \mu \mathrm{L}$. The calculation was done as follows:

$$
\% \mathrm{O}_{2} \text { consumption }=\mathrm{r} / 12.5 \times 100
$$

$\mathrm{r}=0.5 \mathrm{x}$ distance travelled by agonists

where i) speed of oxygen electrode chat recorded (constant) $=0.5 \mathrm{~mm} / \mathrm{min}$, ii) distance travelled by cells with no agonist across the chat graph sheet $=25$ units

Therefore, Speed without agonist $=12.5 \mathrm{~mm} / \mathrm{min}$.

\subsection{Statistics}

Data were expressed as mean $\pm \mathrm{SD}$ and the number of experiments was represented by n. A paired t-test was used to compare average oxygen consumption before and after 
addition of agonists FMLP and PMA to cells. Independent t-test was used to compare average oxygen consumption observed in treatment. Data were analyzed using SPSS and statistical significance between datasets was expressed as $\mathrm{P} \leq 0.05$.

\section{Results}

\subsection{Proliferation of RAW264.7 Cells Resulting from Calcitriol Treatment}

The concentration of cells per $\mathrm{ml}$ obtained increased significantly $(\mathrm{P}<0.05)$ in FMLP stimulated cells $\left(8.67 \times 10^{6}\right.$ cells $/ \mathrm{ml})$ when compared with that of PMA agonist (5.24 X $10^{6}$ cells/ml) sample (Figure 1 ).

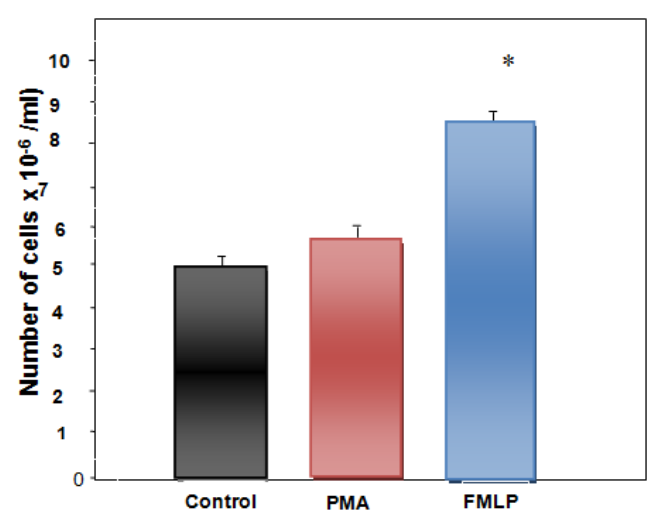

Figure 1. Proliferation of RAW264.7 cells resulting from treatment with calcitriol Average difference observed in concentration per $\mathrm{ml} / \mathrm{cell}$ suspension after 72 hours of incubating $5 \times 10^{6}$ cells $/ \mathrm{ml}$ RAW264.7 cells suspension pre-treated with $20 \mu \mathrm{l}$ of $100 \mu \mathrm{M}$ calcitriol and $990 \mu \mathrm{l}$ PBS. Values were presented as means $\pm S E M, n=3$ independent experiments. *Different from control and $P M A, P<0.05$.

\subsection{Oxygen Consumption of RAW264.7 Cells Exposed to PMA and FMLP after Calcitriol Treatment}

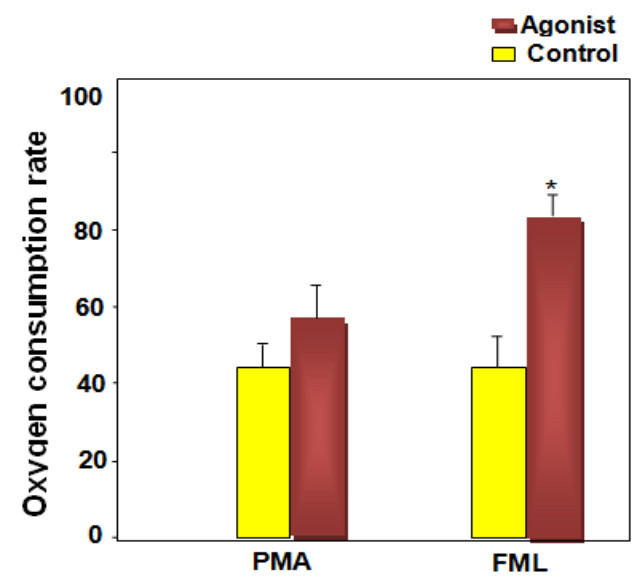

Figure 2. Rate of Oxygen consumption of RAW264.7 cells stimulated with $P M A$ and FMLP expressed as relative percentage. Oxygen consumption induced by treating cells with $1 \mu \mathrm{l}$ of $1 \mu \mathrm{M}$ PMA and $1 \mu \mathrm{l}$ of $10 \mu \mathrm{M}$ FMLP Respiratory burst was investigated by pre-treating $5 \times 10^{6}$ cells $/ \mathrm{ml}$ of

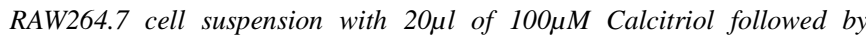
incubation for 72 hours. The results were presented as mean \pm SEM. Asterisks (*) above error bars indicate significant differences $(P<0.05)$ when compared with the control and PMA agonist.
Percentage oxygen consumption was estimated in each PMA and FMLP calcitriol-treated cells after $72 \mathrm{~h}$ incubation time. On comparison the percentage increase $(76 \% ; 14.3$ $\mathrm{mm} / \mathrm{mims}$ ) of oxygen consumption in the calcitriol treated FMLP stimulated cell was significantly higher $(\mathrm{P}<0.05)$ with respect to the control $(4.5 \mathrm{~mm} / \mathrm{mins})$ however, PMA increase $(57 \% ; 6 \mathrm{~mm} / \mathrm{min})$ did not show any significance difference ( $\mathrm{P}>0.05)$ with the control $(4.5 \mathrm{~mm} / \mathrm{mins})$ (Figure 2) . Comparison of the PMA and FMLP stimulated RAW264.7 cells showed a significantly $(\mathrm{P}<0.05)$ increased oxygen consumption in FMLP agonist.

\section{Discussion}

Oxygen consumption in immune cells represents a method of measuring respiratory burst activity in humans. Respiratory burst in macrophages and monocytes may be stimulated either naturally or artificially in the form of particulate bodies. This study was carried out to investigate the possible effect of calcitriol on oxygen consumption stimulated by PMA and FMLP agonists. The stimulation of pre-treated RAW264.7 cell lines could aid in eliciting immunopharmacological action useful in fighting-off diseases. It suffices to say that oxygen consumption corresponds to the generation of reactive oxygen species needful in killing pathogens during induced NADPH-oxidase respiratory burst.

Previous experiments on determination of oxygen consumption performed on RAW264.7 mouse macrophages showed repeatable and consistent measurements which indicate that the oxygen measurements does not adversely affect the physiological state of the cells measured[21]. Several factors have been identified that limit oxygen consumption even when cells are subjected to treatments with established oxygen consumption activators. For example, induction of copper deficiency in RAW264.7 cell lines recorded relatively lower oxygen consumption in the cells when compared with the control (no copper deficiency)[22]. This demonstrates that oxygen limitation promotes a series of striking alterations in copper homeostasis in RAW264.7 macrophage cells.

The results obtained in the study show increased oxygen consumption in calcitriol pre-treated RAW 264.7 cells stimulated by FMLP when compared with PMA agonist. PMA and FMLP are proven stimulators of respiratory burst (measured with respect to intracellular oxygen consumption) in monocytic and macrophage-type cells. Oxygen consumption by stimulated cells has been associated with the NADPH-oxidase subunit (phox47 and phox67) interaction [23 24] in oxidized low-density lipoprotein (oxLDL) [25]. It is of note that calcium supplementation was deliberately used to maintain intracellular calcium ion level and improve agonist-stimulation of oxygen consumption in the cell model used. The presence of the agonist and a high calcium ion may have resulted to increased PKC activation and membrane association.

The mechanism of oxygen consumption initiation by PMAand FMLP-treated cells differs. While PMA stimulates cells 
by directly activating PKC, stimulation by FMLP has been reported to be membrane receptor based [26]. N-formyl peptide receptor (fPR) has been identified as responsible for FMLP-induced NADPH-oxidase activation [27] and an $\mathrm{N}$-formyl peptide receptor-like 1 (FPRL1) molecule has also been reported to be associated with neutrophils [28]. These were considered to be receptors for FMLP stimulation and which mediate cellular activities such as degranulation, chemotaxis and respiratory burst. It is also shown that production of reactive oxygen species is dependent on the concentration of FMLP in wild type mouse neutrophil with intact fPR, whereas in the case of fPR-deficient neutrophils, less of such superoxide anions were produced even with a higher concentration of FMLP [25]. Since FMLP binds to the fPR to stimulate cell processes like release of intracellular calcium and activation of phospholipase $\mathrm{C}$, this in turn triggers the activation of protein kinase $\mathrm{C}(\mathrm{PKC})$ from diacylglycerol leading to the increased action of FMLP as observed in the present study[29].

The overall effect of the NADPH-oxidase function is the transfer of electrons from NADPH through the cell membrane to molecular oxygen in order to generate the reactive oxygen species needed for bactericidal activity. Though the present research did not investigate experimentally the phosphorylation process, other studies investigating activation of NADPH oxidase by PMA revealed a non receptor-mediated mechanism [30].The involvement of a PKC in the stimulation process was therefore strongly suggested.

In the study oxygen consumption was reduced in PMA-treated cells possibly because of unproven inhibitory activities of calcitriol on cytochrome b. Normally, PMA directly activates protein kinase $\mathrm{C}$ which directs phosphorylation of the cytosolic components of the NADPH-oxidase subunits and translocation of the subunits to the membrane-bound cytochrome b 558 complex. Other researchers have reported possible inhibition of cytochrome by certain metabolites such as vitamins [31]. Furthermore, it has been shown that cytochrome $b$ in the presence of inhibitors such as diphenylene iodonium (DPI), exhibits limited oxygen consumption in PMA-treated cells, whereas the DPI causes no limited oxygen consumption in FMLP-treated samples [32]. Conversely, FMLP stimulation is receptor based and there is no direct involvement with protein kinsase C [33] as seen in PMA.

\section{Conclusion}

Calcitriol treated RAW264.7 cell stimulated by the agonist FMLP increased oxygen consumption in cells, thus may be useful in the control and design of drugs with intended immunopharmacological activity.

\section{Study Limitation}

The study did not measure superoxide ions concentration and NADPH oxidase activity.

\section{References}

[1] Belikova I, Lukaszewicz AC, Faivre V, Damoisel C, Singer M, Payen D. "Oxygen consumption of human peripheral blood mononuclear cells in severe human sepsis". Crit Care Med. 35(12). 2702-8.2007

[2] Kvarstein B, Blichfeldt P. "Oxygen Consumption During Phagocytosis by Leukocytes in Patients with Rheumatic Diseases" Scand J Rheumatol.6 ( 3):148-150.1977.

[3] Dawn Bowdish. Propagation \& Culturing of Raw264.7 cells. 2013

http://www.bowdish.ca/lab/wp-content/uploads/2013/02/Cultu ring-RAW264.7-Cells.pdf

[4] Dyer KD, Schellens IMM, Bonville CA, Martin BV, Domachowske JB, Rosenberg HF: "Efficient replication of pneumonia virus of mice (PVM) in a mouse macrophage cell line". Virol Journal. 4:48-5.2007.

[5] Rowley CA, Ikeda AK, Seidel M, Anaebere TC, Antalek MD, Seamon C, Conrey Ak, Mendelsohn L, Nichols J,Gorbach AM, Kato GJ, Ackerman H. "Microvascular oxygen consumption during sickle cell pain crisis". Blood. 123 (20): 2014. DOI: http://dx.doi.org/10.1182/blood-2013-11-533406

[6] Shin J-J, Wall EA, Zavzavadjian JR, Santat LA, Liu J, Hwang J-I, Rebres R, Roach T, Seaman W, Simon MI, Fraser IDC: “A single lentiviral vector platform for microRNA-based conditional RNA interference and coordinated gene expression”. Proc Natl Acad Sci USA. 103:13759-13764.2006.

[7] Walloschke B, Fuhrmann H, Schumann J. "Macrophage cell line RAW264.7 but not P-388D1 is an appropriate in vitro-model for studying oxidative burst as well as cytokine production in context of fatty acid enrichment". Cell Immunol. 262(1):58-61. 2010.

[8] Xiaohui Wang, Yidong Li, Xiaoyan Zhu, Yan Wang, Fei Diao, Jian Lu. "Signal regulatory protein a1 is involved in the inhibitory effect of glucocorticoid receptor on the proliferation of murine macrophage RAW264.7 cell and mouse peritoneal macrophage". Journal of Molecular Endocrinology. 41:393-403.2008.

[9] Vittorina DB, Miroslawa G, Filoppo R. "Relationship between phosphorylation and translocation to the plasma membrane of p47 phox and p67 phox and activation of the NADPH oxidase in normal and $\mathrm{Ca} 2+$ depleted human neutrophils". Biochem J 290:173-178.1993.

[10] Bruce A, Johnson A, Lewis J, Raff M, Roberts K, Walters P. "Molecular Biology of the Cell" Fourth Edition. New York and London: Garland Science.2002.

[11] Finlay B, McFadden G. "Anti-immunology: evasion of the host immune system by bacterial and viral pathogens". Cell 124 (4): 767-82.2006.

[12] Clark RA. "Activation of the Neutrophil Respiratory Burst Oxidase”. J Infect Dis 179(S 2): S309-S317. 1999.

[13] Simchowitz L, Atkinson JP, Spilberg I, Arthritis Rheum. "Stimulation of the respiratory burst in human neutrophils by crystal phagocytosis". Arthritis Rheum. 2:181-8.1982.

[14] DeLeo FR, Quinn MT. "Assembly of the phagocyte NADPH oxidase: molecular interaction of oxidase proteins". J Leukocyte Biol. 60:677-9.1996. 
[15] Narayanan PK, Carter WO, Ganey PE, Roth RA, Voytik-Harbin SL, Robinson JP. "Impairment of human neutrophil oxidative burst by polychlorinated biphenyls: inhibition of superoxide dismutase activity". J Leukocyte Bio. 63: 216-224.1998.

[16] Mates JM, Perez-Gomez C, Blanca M. "Chemical and biological activity of free radical scavengers' in allergic diseases". Clinica Chimica Acta. 296: 1-15.2000.

[17] Jiang F, Zhang Y, Dusting GJ. "NADPH Oxidase-Mediated Redox Signaling: Roles in Cellular Stress Response, Stress Tolerance, and Tissue Repair". Pharmacol Rev 63(1): 218-242.2011.

[18] Griendling KK, Sorescu D, Ushio-Fukai M. "NAD(P)H oxidase: role in cardiovascular biology and disease". Circ Res. 86: 494-501.2000.

[19] Lambeth JD. "NOX enzymes and the biology of reactive oxygen”. Nat Rev Immunol. 4:181-189.2004

[20] Diepart C, Verrax J, Calderonb JB, Feronc O, Jordana BF, Gallez B. "Comparison of methods for measuring oxygen consumption in tumor cells in vitro". Anal Biochem. 396 : 250-256.2010.

[21] Dragavon J, Molter T, Young C, Strovas T, McQuaide S, Holl M, Zhang M, Cookson B, Alex Jen A, Lidstrom M, Meldrum D,Burgess L. "A cellular isolation system for real-time single-cell oxygen consumption monitoring." J. R. Soc. Interface 25 ( Suppl 2 ): S151-S159.2008.

[22] White C, Kambe T, Fulcher YG, Sachdev SW, ${ }^{2}$ Bush AI, Fritsche $\mathrm{K},{ }^{4}$ Lee J, Quinn TP, Petris MJ. "Copper transport into the secretory pathway is regulated by oxygen in macrophages". J Cell Sci. 122(9): 1315-1321.2009.

[23] Suh C, Stull ND, Li XJ, Tian W, Price MO, Grinstein S, Yaffe MB, Atkinson S, Dinauer, MC. "The phosphoinositide-binding protein $\mathrm{p}^{\text {phox }}$ activates the NADPH oxidase during Fc gammer IIA receptor-induced phagocytosis". JEM . 203(8): 1915-1925.2006.

[24] Shiose A, Sumitomo H. Arachidonic acid and phosphorylation synergistically induce a conformational change of p47 phox to activate the phagocyte NADPH oxidase. J Biol Chem. 275: 13793-801.2000.
[25] Heinloth, Heermeier K, Raff U, Wanner C, Galle J. Stimulation of NADPH oxidase by oxidized low-density lipoprotein induces proliferation of human vascular endothelial cells. $J \mathrm{Am}$ Soc Nephrol. 11:1819-1825.2001.

[26] Schwende H, Fitzke E, Ambs P, Dieter P. "Differences in the state of differentiation of THP-1 cells induced by phorbol ester and 1, 25-dihydroxyvitamin D3". J Leukocyte Biol. 59: $555-561.1996$.

[27] Mark C, Philip M, Thomas LL, Ji-Liang G. "The $N$-formylpeptide receptor (FPR) and a second $\mathrm{G}_{\mathrm{i}}$-coupled receptor mediate fMet-Leu-Phe-stimulated activation of NADPH oxidase in murine neutrophils". Cellular immunology. 218(2): 7-12.2002.

[28] Selvatici R, Falzarano S, Mollica A, Spisani S. "Signal transduction pathwas triggered by selective formylpeptide analogues in human neutrophils". Eur. J. Pharmacol. 534:1-11.2006

[29] Mills JS., Miettinen HM, Jesaitis AJ. "The N-formyl peptide receptor: structure, signaling, and disease". C. N. Serhan, and P. A. Ward, eds. Molecular and Cellular Basis of Inflammation 215-246. Humana Press, Totowa. 1999.

[30] Shiose A, Sumitomo H. "Arachidonic acid and phosphorylation synergistically induce a conformational change of p47 phox to activate the phagocyte NADPH oxidase". J Biol Chem. 275: 13793-801.2000.

[31] Tam TW, Akhtar H, Arnason1 JT, Cvijovic K, Boon H, Cameron DW, EDrouin C, Jaeger W, Tsuyuki RT, Vohra S, Foster BC. "Inhibition of Human Cytochrome P450 Metabolism by Blended Herbal Products and Vitamins". J Pharm Pharmaceut Sci. 14(1): 1-16.2011.

[32] Ellis JA, Mayer SJ, Jones OT. "The effect of the NADPH oxidase inhibitor diphenyleneiodonium on aerobic and anaerobic microbial activities of human neutrophils". Biochem J. 251(3) 887-891.1988.

[33] Valerie BO, David GT, Owen TG, Paul J. "Studies on the inhibitory mechanism of iodonium compounds with special reference to neutrophil NADPH oxidase". Biochem. $J$. 290(1):41-49.1993. 